\title{
A Study on the Restriction of the Legitimate Purposes of Shareholders' Inspection Right from an International Perspective
}

\author{
Shurong $\mathrm{Wu}^{1}$, Jialin $\mathrm{Li}^{2}$ \\ ${ }^{1}$ Sichuan GongShengMing Law Firm, Chengdu 610017, Sichuan, China \\ ${ }^{2}$ The People's Procuratorate of Xindu, Chengdu 610500, Sichuan, China
}

\begin{abstract}
With the separation of shareholders'ownership and control of a company, the law of China should not only constantly expand the scope of protection of shareholders' right to information, but also improve the protection measures accordingly. As a major right of shareholders, inspection right is the basis and prerequisite for shareholders to exercise other rights. Under the lure of power, if shareholders' right to obtain corporate information cannot be reasonably protected, it will be inevitable for the operators of the company to manipulate the information and thus violate the interests of shareholders. The provisions of article 33, paragraph 2 of Company Law of China relating to shareholders' right to information are too brief and to a degree, not viable and feasible. Furthermore, in judicial practice, the meaning of legitimate purposes varies with different judges, leading to different standards and different decisions even in some virtually similar cases. Although the Interpretation of Company Law (IV) tries to solve the above judicial dilemma, there are still some deficiencies in the definition of legitimate purpose. Therefore, in order to enhance the right of the shareholders' inspection, it is desperately necessary to learn from the relevant experience of extraterritorial law. This paper, by mainly analyzing the regulations of Japan and Germany on shareholders' right to inspection, concludes that the Company Law of China can make changes on the following four aspects: refining the judgment standards for legitimate purposes, clarifying the connotation of legitimate purposes, expanding the domain of application of the shareholders' inspection right and introducing the inspector system.
\end{abstract}

Keywords: Shareholders' inspection right, Legitimate purpose, Limited liability company, Extraterritorial law.

\section{Review of the Rules on the Restriction of Legitimate Purpose of Shareholders' Inspection Right}

1.1 The Introduction of the Shareholder's Inspection Right in Article 33 Paragraph 2 of the Company Law

Article 33 Paragraph 2 of the Company Law of China explicitly stipulates the shareholders' right of inspection in a limited liability company and also the formal requirements for realizing the right of inspection. Nevertheless, in judicial practice, this article can hardly have the due effect in the process of application. Firstly, to take a very elementary example, as for the subject of audit right, this article only stipulates the shareholders in limited liability company, and non-shareholders of joint stock limited liability company are, however, authorized to exercise inspection right. That is to say, the limit of subject is fairly narrow. Secondly, with regard to scope of inspection, there still exists obvious defects. The company's accounting books is not available for shareholders, with the result that shareholders cannot access the crucial information and know the particular problems and true statements of the company. Thirdly, on literal meaning, there is no detailed explanation of relevant terminology. For example, whether the term "consult" includes "extract" and "copy". Fourthly, when it comes to constitutive elements, this article only simply prescribes the term "illegitimate purpose", but totally omits the clear connotation and specific scope of "illegitimate purpose", which is prone to cause ambiguity in judicial practice. Fifthly, on forms of judicial relief, the provisions of Article 33 of the Company Law are oversimplified, and it is safe to say that the stipulation is not viable and feasible.
1.2 The Specification of the Restrictions on the Legitimate Purpose of Shareholders' Inspection Right in Interpretation of the Company Law (IV)

In 2017, the Interpretation of the Company Law (IV) was decreed by the Supreme People's Court. According to this interpretation, articles of 7 to 11 further specify the exercise of shareholders' inspection rights and the article 8 reversely defines the "legitimate purpose" of shareholders' access to accounting books in paragraph 2 of Article 33 of the Company Law, prescribing precisely which circumstances should be deemed as illegitimate purpose by judges in judicial practice. Undoubtedly, such provision can contribute to the protection of the exercise of the shareholders' inspection in a sense, but the specific conditions for its application still need to be further discussed and studied.

In detail, paragraph 1 of this article provides that, in principle, all shareholders who have competing relationship with the company in the same industry are not entitled to audit rights. This paper believes that such absolute provision is inappropriate. There are two reasons: firstly, from the perspective of fairness, even as competitors in the same industry, the company's shareholders still have interests in the company and at the same time, there is a risk that the shareholders' rights and interests will be infringed by major shareholders and company managers. In other words, such kind of provision will deprive the shareholders' inspection right and lacks fair consideration. Secondly, from the perspective of legality, unless specially stipulated in the articles of association or agreed by all other shareholders, a shareholder has no non-competition obligation to the company, so indeed, there is no legal basis for depriving the 
shareholders' audit rights. In addition, subparagraph 3 of the article provides for the punishment of shareholders' dishonest acts and previous acts by means of legal presumption. In terms of this applicable definition, there are two different views in academic fields. One view is that, to a degree, this provision can reflect the value orientation of protecting the interests of the company. And the other view holds that it is unreasonable to assume that the current behavior is not based on legitimate purpose only by analyzing the previous behavior, since the logical argument is not rigorous and does not meet people's reasonable expectations and needs. The author tends to support the negative theory because the purpose of the shareholders' behaviors in three years cannot be presumed to be illegitimate only by virtue of a certain behavior. In addition, paragraph 4 of this article is a bottom-saving provision, and its purpose is to make up for the inadequacy of the above three provisions. So the word "others" should have equal value and the homogeneity of evaluation criteria with the first three paragraphs.

\section{Extraterritorial Regulation on the Restriction of Legitimate Purpose of Shareholders' Inspection Right}

There are great differences between common law countries and civil law countries on the connotation of "legitimate purpose". In common law countries, such as the United States and the United Kingdom, the connotation mostly adopts generalized provisions. But as one of the representatives of civil law countries, Japan, often uses enumeration rules to list the concrete conditions that constitute legitimate purposes. This paper mainly selects the provisions of Japan and Germany on shareholder's right of access to accounting books, and tries to provide reference for China to perfect the relevant provision.

\subsection{Provisions of Japan on the Legitimate Purpose of Shareholders' Inspection Right}

On the whole, Japan chooses the enumerative legislative model and lists five cases of illegitimate purposes. The relevant legal provisions of Japan's Commercial Code stipulate that directors shall not arbitrarily refuse shareholders to exercise the right to inspect accounting books, if the shareholders' right to inspect accounting books meets the five listed legitimate purposes. In addition, the relevant legal provisions in The Japanese Company Code also list the following five cases with illegitimate purpose through reverse enumeration: First of all, shareholders have competitive relationship with the company in the same industry. Because in this case, it is difficult to balance the interests between the shareholders and the company when shareholders exercise the right of checking accounting books, inevitably resulting in conflicts and antagonism; Secondly, the shareholder, as the claimant to accounting book access, has provided the copy or access to the relevant core confidential information to any third party within the past two years; Thirdly, the shareholders' purpose is contrary to the core value and interests of the company or irrelevant to the management of the company, for it is wildly known that the shareholder's investment purpose is for the better operation and management of the company; Fourthly, if there is a risk of damaging the interests of the company and other shareholders, seriously affecting the operation and management of the company, and causing the company to fall into a difficult situation when shareholders exercise the right of access to accounting books, and the director may safely draw a conclusion that the shareholders have illegitimate purpose; Finally, the shareholders exercise the right to inspect accounting books for the purpose of providing the company's operation and management information and core confidential information to a third party. (Wang Zuoquan, 2012, p.435) This regulation can effectively prevent the abuse of shareholders' rights to a large extent. (Wang Zuoquan, 2016, p.249) From the relevant provisions of Japan, it can be seen that Japan pursues a balance between efficiency and rights protection in the legitimate purpose restriction of shareholders' right of inspection, which highlights the maturity and carefulness of Japanese commercial legislation that borrows from the experience of Germany.

\subsection{Provisions of German on the Legitimate Purpose of Shareholders' Inspection Right}

As Japan's provisions, Germany Law also adopts general legislation in this regard. Specifically, the relevant legal provisions of the German Limited Liability Company Act stipulate that if any company investor requests an account audit, the respondent shall immediately provide the company's relevant information and materials of the company's operating condition and guarantee the investors' right of inspection. The second paragraph of this law follows the provision of illegitimate purposes: If the director fears that the shareholders will audit the accounts for illegal purposes and cause a large loss to an associated enterprise, he may refuse the investor's application, but the decision of refusing must be approved by the shareholders' meeting (Hu Xiaojing and Yang Daixiong, 2014, p.46). It can be seen from this provision that the shareholders with limited liability of the German limited liability company can request for inspection and are entitled to inspect the account books, but the executor of the limited liability company can refuse their requests when they can prove that the shareholders have no legitimate purpose and they may cause the affiliated enterprise to suffer losses. German stock corporation law regulation, however, compared with the German limited liability company law is different, stipulating that the shareholders of the joint-stock company can be allowed to exercise the audit right only during the session of the general meeting of shareholders and under certain circumstances. That is to say, compared with the limited liability company, the German regulations on shareholders' right of inspection are slightly stricter.

\section{Judicial Dilemma of Restricting the Legitimate Purpose of Shareholders' Inspection Right}

In the first place, the enumerated delimitation can easily lead to the abuse of the shareholder's right of inspection. Because the current company law does not have a clear definition of 


\begin{abstract}
"legitimate purpose" and lacks a clear connotation of "illegitimate purpose", and the interpretation (IV) of the Company Law adopts the form of generalization, enumeration and reverse provisions, which only defines four circumstances that constitute "illegitimate purpose". In addition, the purposes that can be used for shareholders to apply for inspection are various and miscellaneous. Therefore, it is by no means easy to summarize the enormously complex situations in real life just according to the four circumstances listed in the provision. The superposition of the above problems posed by the provisions can easily lead to different standards of recognizing "legitimate purposes", different application of provisions and different judgments in some virtually same cases, which can reduce the judicial credibility and result in the abuse of shareholders' inspection right (Shao Yaxiang, 2015, p.126).
\end{abstract}

What's more, the scope of objects restricted by legitimate purposes is limited, too. In detail, Article 7 of the Interpretation of the Company Law (IV) stipulates that shareholders can access specific financial data, but in judicial practice, shareholders cannot access the original accounting vouchers of the company. In the final analysis, it is because the current law and regulations in China do not clarify the scope of financial data. And in the recognition of the legitimate purpose of the original accounting documents, Chinese legislation is still blank. At present, it is difficult to fully find the problems existing in the company's operation only by consulting the accounting books. In other words, if shareholders can access accounting documents, it is bound to improve the effectiveness of shareholders' right to information, (Chang Junwei, 2013, p.89) and help shareholders improve the rationality of expressing their demands (Du Wanhua, 2017, p.92).

Finally, the criterion for identifying the subjective purpose of the shareholder's inspection right needs to be improved. The distribution of the burden of proof for "legitimate purpose" is critically important to both scope and measures of protection of shareholders' access to accounting books (Li Jianwei, 2010, p.118). And one of the main reasons why it is difficult to protect shareholders' right to information is just that the standard of proof of legitimate purpose for shareholders to bear is too high. The four provisions on shareholders' right to information in Interpretation of Company Law (IV) cover a wide range. Although the interpretation not only provides judges with certain examination standards but also elaborates certain judgment requirements, they cannot fully reflect the requirements of protecting shareholders' core interests. The provisions of clause 4, Article 8 of the Interpretation of Company Law (IV) are vague and lack of specificity and clarity, which is easy to cause inconsistent standards of judges' determination in judicial practice. In addition, there is no provision in the Interpretation of Company Law (IV) on the distribution of burden of proof for legitimate purposes, resulting in unclear burden of proof in judicial practice (Wang Daina, 2017, p.76).

\section{Optimization Path of Legitimate Purpose's Restriction of Shareholders' Inspection Right}

\subsection{Maintaining the Balance of Interests Between Shareholders and the Company}

The Company Law should not only fully protect the overall rights and interests of the company, but also attach great importance to the protection of the inherent interests of shareholders. The exercise of inspection right by shareholders is a specific request made by shareholders based on right of self-interest or co-interest. In the process of reviewing whether the purpose is legitimate, the principle of balance of interests is a basic principle throughout the disputes of shareholders' right to information. While protecting the inherent right of shareholders' inspection right, it is necessary to avoid the expanded interpretation of the scope of "illegitimate purpose" by the court and should explain it from the perspective of maintaining the balance between the inherent interests of shareholders and the interests of the company as far as possible. The scope of the exercise of shareholders' inspection right should be consistent and related to the demand for information. Shareholders' inspection of accounting books must follow the principle of equal rights and obligations, and the purpose of audit should be clear and detailed, so as to avoid the imbalance of interests between shareholders and the company.

\subsection{Clearly Defining the Connotation of "Legitimate Purpose"}

On the issue of defining the meaning of "legitimate purpose", the Interpretation of the Company Law (IV) lists several circumstances of illegitimate purpose, which lacks a positive definition of the connotation of "legitimate purpose", so that judges can not accurately grasp the "legitimate purpose" in the process of adjudication, and then the review of "illegitimate purpose" becomes a tough task. Hence, by referring to the provisions of the Delaware company law of the United States, firstly, the basic connotation of legitimate purpose is clearly defined from the positive side, that is, "legitimate purpose refers to the legitimate and reasonable intention related to the personal interests of shareholders", and then the review can be conducted from the negative side, illegitimate purpose. After an inquiry to both positive and negative aspects, the judge can examine accurately the inspection intention of shareholders, and then determine whether the shareholders are qualified for inspection. In addition, in the process of identifying "legitimate purpose", judges should focus on the legitimacy, relevance and specificity of the purpose of inspection, that is, the purpose for shareholders to exercise the right of inspection should comply with the provisions of the law, the content required by shareholders to inspect has a certain connection with its purpose, and the purpose of inspection should be specific and 
clear. Only by reviewing from these three aspects can directors effectively prevent shareholders from abusing their right to information and causing undue damage to the company.

\subsection{Expanding the Domain of Application of the Restriction on the Purpose of Shareholders' Inspection Rights}

Article 33 of the Company Law only stipulates that shareholders have the right to inspect the company's accounting books, but does not specify whether the original documents can be inspected. In practice, the slightly lenient approach of most Chinese courts is indicated by decisions of the higher People's courts in many places that shareholders are entitled to check the original vouchers and accounting vouchers of the company. It reveals that in judicial practice, courts in China have in fact recognized the scope of access to original documents. At present, Chinese regulations on the scope of shareholders' inspection right are too limited. As we know, the acquisition of accounting document is based on the actual business activities of the company. If the shareholders can start from the original source, the company's business situation and financial information will be restored accurately to a large extent. Therefore, the limitation and definition of legitimate purpose should be extended to the original accounting documents. At the same time, it can also be considered to exercise the right of access to the actual participants, actual business sites and the contents of accounting books. There is no doubt that the expansion of the scope of shareholders' right to information has become an indispensable way for companies in all countries to develop and grow. And accordingly, China should adopt a more open legislative model to provide shareholders with more appropriate and flexible protection.

\subsection{Introducing the Inspector System}

The advantage of the inspector system in the United States, The United Kingdom and Japan lies in that it can play the role of "equalizing instrument" between shareholders' rights of inspection and the interests of the company, maximizing the interests of both parties. China can learn from the advanced experience of foreign countries in this aspect of the system, and establish the inspection system in accordance with current conditions of the socialist market economy system, which can not only effectively prevent shareholders from consulting the company's accounting books on their own to damage the company's commercial secret, but also fully embodies the principle of protecting shareholders' right to information. And shareholders need to provide evidence and explain that they have legitimate purposes for auditing accounts before they access the company's core confidential information. At the same time, shareholders can request the shareholders' meeting and the court to appoint inspectors in accordance with the principle of neutrality. The inspectors can be lawyers, accountants, special inspectors and other professionals. And the inspector shall conduct an in-depth and meticulous investigation of the company's internal operation or relevant information, and undertake the obligation of confidentiality, otherwise they shall bear certain liability for breach of contract or tort. All in all, China should explore and establish a set of inspector system to adapt to the development model of socialist market economy with Chinese characteristics, so as to better promote the development and improvement of the system of shareholders' right to information.

\section{References}

[1] Wang Zuoquan. Introduction to Company Law, Peking University Press, 2012: 435.

[2] Wang Zuoquan. Newly Revised Corporate Code of Japan, Peking University Press, 2016: 249.

[3] $\mathrm{Hu}$ Xiaojing, Yang Daixiong. German Commercial Company Law, Law Press, 2014: 46.

[4] Shao Yaxiang. Comparative study on shareholders' right to information, Journal of China University of Political Science and Law, 2015(4): 126.

[5] Chang Junwei. Path choice for standardized exercise of shareholders' right to inspection, People's Justice, 2013 (17): 89

[6] Du Wanhua. Understanding and application of the judicial interpretation (IV) of the Company Law of the Supreme People's court, People's Publishing House, 2017: 92.

[7] Li Jianwei. Analysis on the basic procedural issues of shareholders' right to information litigation, Journal of National Prosecutors College, 2010 (1): 118.

[8] Wang Daina. Research on several controversial issues of shareholders' right to information in limited liability companies - understanding and thinking based on the fourth judicial Interpretation of the Company Law (Exposure Draft), Present Day Law Science, 2017 (2): 76. 